\title{
Analisis Perbandingan Reaksi Investor Sebelum Dan Sesudah Pengumuman Indonesia Sustainability Reporting Awards (ISRA)
}

(Studi Kasus Pada Perusahaan Penerima Penghargaan ISRA Periode 2016)

\author{
Dwi Yana Amalia Sari Fala \\ Septy Indra Santoso \\ Ariska AmandA \\ Dwiyana_fala@yahoo.com \\ muhammadindrasantoso@gmail.com \\ ariskaamanda@yahoo.com \\ Universitas Khairun, Ternate
}

\begin{abstract}
The purpose of this research to analyze the reaction of investors, as measuring by differences in abnormal returns and trading volume activity before and after the announcement of Indonesia sustainability reporting awards in 2016. Using purposive sampling method was obtained Sample of research 10 companies with observation for three days before and three days after announcement. The Hypothesis testing used paired sample t-test. Results of the first hypothesis testing show that happen differences abnormal return before and after the announcement of Indonesia sustainability reporting awards but not significant, testing the second hypothesis too shows that are differences in trading volume activity before and after the announcement of Indonesia sustainability reporting awards but not significant.
\end{abstract}

Keywords: investor reaction, abnormal return, trading activity volume

\begin{abstract}
ABSTRAK
Penelitian ini bertujuan untuk menganalisis reaksi investor, yang diukur dengan perbedaan abnormal return dan trading volume activity sebelum dan sesudah pengumuman Indonesia sustainability reporting awards pada tahun 2016. Menggunakan metode purposive sampling diperoleh Sampel penelitian sebanyak 10 perusahaan dengan observasi selama tiga hari sebelum dan tiga hari sesudah pengumuman. Pengujian hipotesis menggunakan uji paired sample t-tes. Hasil pengujian hipotesis pertama menunjukan bahwa terdapat perbedaan abnormal return sebelum dan sesudah pengumuman Indonesia sustainability reporting awards namun tidak signifikan, pengujian hipotesis kedua juga menunjukan bahwa terdapat perbedaan trading volume activitysebelum dan sesudah pengumuman Indonesia sustainability reporting awards namun tidak signifikan.
\end{abstract}

Kata kunci :reaksi investor, abnormal return, trading volume activity 


\section{PENDAHULUAN}

Dalam suatu perusahaan, penilaian investor sangat penting untuk meningkatkan nama baik perusahaan sehingga terjaga citra yang positif serta meningkatkan daya saing perusahaan. Sebuah perusahaan yang baik harus mampu mengontrol potensi finansial maupun potensi non finansial didalam meningkatkan nilai perusahaan untuk eksistensi perusahaan dalam jangka panjang.Memaksimalkan nilai perusahaan sangat penting artinya bagi suatu perusahaan, karena dengan memaksimalkan nilai perusahaan berarti juga memaksimalkan kemakmuran pemegang saham yang merupakan tujuan utama perusahaan.Menurut Brigham dan Houston (2001) nilai perusahaan merupakan harga yang bersedia dibayar oleh calon pembeli apabila perusahaan tersebut dijual.

Pada awalnya perusahaan hanya dibangun dengan paradigma lama berupa single $P$ alias Profit saja. Dengan pergeseran bisnis terdapat paradigma baru dalam menentukan kemajuan suatu perusahaan yaitu Sustainability Reporting. Sustainability Reporting bagi perusahaan merupakan publikasi informasi yang mencerminkan kinerja organisasi dalam dimensi ekonomi, sosial dan lingkungan (ACCA, 2013). Sustainability Reporting adalah informasi keuangan dan non keuangan yang bermanfaat bagi para pemangku kepentingan mengenai kegiatan ekonomi, sosial dan lingkungan yang dijalankan perusahaan (Segger dan Marie, 2003). Sustainability Reporting dapat dipahami sebagai cara perusahaan untuk menjawab permintaan stakeholders mengenai manajemen resiko dan informasi mengenai kinerja perusahaan (Ballou et.al, 2006). Jadi, Sustainability Reporting adalah laporan keuangan dan non keuangan yang dipublikasikan oleh perusahaan melalui informasi-informasi yang terdapat di dalam ruang lingkup perusahaan dan kegiatan ekonomi, sosial dan lingkungan. Perusahaan yang telah go public memiliki kewajiban membuat laporan keberlanjutan (Sustainability Report).

Perhatian investor dan calon investor terhadap pelaporan ekonomi lingkungan dan sosial semakin meningkat seiring dengan banyaknya kasus lingkungan yang terjadi di Indonesia. Kasus - kasus seperti pencemaran Teluk Buyat pada tahun 2004 yang dilakukan PT Newmont Minahasa Raya. Kasus lumpur lapindo pada tahun 2006 yang dilakukan PT Minamark Lapindo di Sidoarjo Jawa Timur. Kasus pencemaran udara berupa asap hasil pembakaran limbah pada tahun 2008 yang dilakukan PT Hanil Indonesia di Napen Jawa Tengah. Kasus pencemaran sungai Citarum pada tahun 2014 yang diduga dilakukan oleh 71 perusahaan (Randika dan Yeterina, 2014). Satyo (2005) mengatakan bahwa para investor mengalami perubahan pandangan investasi, dengan mulai mempertimbangkan kepedulian 
perusahaan terhadap lingkungan. Menurut Hill et al. (2007) sebagaimana dikutip oleh Daniri (2008) menyebutkan bahwa perusahaan yang menerapkan CSR akan mengalami kenaikan harga saham dan kinerja perusahaan akan lebih bagus jika dibandingkan dengan perusahaan yang tidak menerapkan CSR. Berdasarkan penelitian yang lain Eipsteindan Freedman (1994) dalam Anggraini (2006) menemukan bahwa investor tertarik terhadap informasi sosial yang dilaporkan dalam laporan keuangan.

Perusahaan-perusahaan yang memenangkan Indonesia Sustainability Reporting Award (ISRA) akan mendongkrak citra perusahaan dimata publik, karena telah meraih penghargaan yang mengedepankan keselarasan antara aspek ekonomi, sosial, dan lingkungan.Selain itu, perusahaan-perusahaan yang memenangkan penghargaan juga akan merasakan perubahan harga saham mereka, yang dapat dilihat dari abnormal return saham dan volume perdagangan saham perusahaan.Sebagaimana penjelasan dalam teori signaling, informasi ISRA bisa saja dapat dijadikan komunikasi kepada investor untuk mempertimbangkan investasinya, serta dapat melihat respon pasar mengenai pengumuman ISRA, sebagaimana gambaran dalam teori efisiensi pasar. Abnormal return merupakan selisih antara return yang sesungguhnya dibandingkan dengan return ekspektasi (Hartono, 2010). Terjadinya peningkatan return merupakan reaksi positif dari pasar yang ditunjukan dengan perubahan harga dari sekuritas yang bersangkutan. Reaksi ini biasanya diukur dengan menggunakan abnormal return Budiman at al (2009). Apabila pengumuman tersebut mengandung informasi, maka pasar akan menunjukan perubahan harga, reaksi pasar yang menunjukan perubahan harga tersebut dapat diukur dengan abnormal return saham Budiman at al, (2009). Volume perdagangan saham merupakan indikator yang digunakan untuk menunjukan besarnya minat investor pada suatu saham. Semakin besar volume perdagangan, berarti saham tersebut sering ditransaksikan Budiman at al, (2009) dan volume perdagangan saham digunakan sebagai ukuran untuk melihat apakah investor menilai sebuah pengumuman sebagai sinyal positif atau negatif, dalam artian apakah informasi tersebut membuat keputusan perdagangan di atas perdagangan normal (Savitri, 2001 dalam Budiman at al, 2009).

Hasil penelitian Maharrani (2014) terkait reaksi investor perusahaan-perusahaan yang memperoleh penghargaan dengan perusahaan-perusahaan yang tidak memperoleh penghargaan ISRA 2011, hasil abnormal return yang sama (tidak ada perbedaan). Hasil penelitian Harun (2014) terkait reaksi investor terhadap pengumuman Indonesia Sustainability Report Award (ISRA) Studi pada perusahaan peserta ISRA periode 2011 2013.Hasil penelitian menunjukkan reaksi invetor positif terhadap perusahaan peraih 
penghargaan ISRA hasil perhitungan independent sample test membuktikan bahwa terdapat perbedaan perusahaan yang mendapatkan penghargaan ISRA dengan reaksi investor perusahaan yang tidak mendapat penghargaan ISRA. Hasil penelitian Budiman dan Supatmi (2009) terdapat perbedaan abnormal return sebelum dan setelah pengumuman, namun tidak terdapat perbedaan volume perdagangan saham disekitar pengumuman. Hasil penelitian Linuwih dan Nugrahanti (2014) bahwa tidak terdapat perbedaan abnormal return saham di seputar pengumuman ISRA, sedangkan pengujian terhadap volume perdagangan saham menunjukkan perbedaan volume perdagangan saham di seputar pengumuman ISRA, khususnya pada lima hari dan dua hari sebelum pengumuman, serta pada hari pertama dan hari kedua setelah pengumuman. Hasil penelitian Purnawasari (2017) bahwa tidak terdapat perbedaan reaksi pasar sebelum dan sesudah pengumuman Indonesia Sustainability Reporting Award (ISRA) periode 2012 - 2016.

Berdasarkan latar belakang yang telah diuraikan maka rumusan masalah pada penelitian ini yaitu : (1) Apakah terdapat perbedaan abnormal return sebelum dan sesudah pengumuman penghargaan ISRA periode 2016 ? (2) Apakah terdapat perbedaan trading volume activity sebeum dan sesudah pengumuman penghargaan ISRA periode 2016 ?

\section{KERANGKA TEORETIS DAN PENGEMBANGAN HIPOTESIS Teori sinyal (Signailling Theory)}

Signalling Theory atau teori sinyal dikembangkan oleh Ross (1977), menyatakan bahwa pihak eksekutif perusahaan memiliki informasi lebih baik mengenai perusahaannya akan terdorong untuk menyampaikan informasi tersebut kepada calon investor agar harga saham perusahaannya meningkat. Hal positif dalam signalling theory dimana perusahaan yang memberikan informasi yang bagus akan membedakan mereka dengan perusahaan yang tidak memiliki "berita bagus" dengan menginformasikan pada pasar tentang keadaan mereka, sinyal tentang bagusnya kinerja masa depan yang diberikan oleh perusahaan yang kinerja keuangan masa lalunya tidak bagus tidak akan dipercaya oleh pasar (Wolk dan Tearney dalam Dwiyanti, 2010).

Para investor membutuhkan berbagai informasi terkait dengan aktivitas perusahaan yang digunakan dalam pengambilan keputusan. Oleh karena tumbuh kembang perusahaan bergantung pada dukungan dari para investornya, maka perusahaan akan berusaha untuk memberikan berbagai informasi yang bermanfaat bagi investor dalam mengambil keputusan. Pengungkapan informasi dapat dibagi menjadi dua yakni yang sifatnya wajib (mandatory) dan sukarela (voluntary). Salah satu bentuk pengungkapan sukarela yang berkembang pesat 
saat ini yaitu sustainability report. Menurut Ghozali dan Chariri (2007) dalam Widianto at al (2011), melalui sustainability report (pengungkapan sosial dan lingkungan) perusahaan dapat memberikan informasi yang lebih cukup dan lengkap berkaitan dengan kegiatan dan pengaruhnya terhadap kondisi sosial masyarakat dan lingkungan

\section{Laporan Keberlanjutan (Sustainability Report)}

Sekarang ini perusahaan dihadapkan pada masalah bahwa tanggung jawab mereka bukan hanya menyampaikan aspek keuangan saja, yang berupa laporan keuangan perusahaan.Masalah seperti Global Warming dan keterbatasan-keterbatasan yang dimilki laporan keuangan, membuat perusahaan harus memperhatikan aspek non keuangan untuk menjamin umur mereka. Umur perusahaan dapat terjamin apabila faktor keuangan dan faktor non keuangan berjalan seimbang. Laporan keuangan yang merupakan aspek keuangan dan laporan tanggung jawab sosial dan lingkungan perusahaan yang merupakan aspek non keuangan dapat digabungkan oleh perusahaan sebagai bentuk laporan yang memiliki kelengkapan dan keakuratan bagi pihak-pihak terkait, laporan ini sering disebut dengan laporan keberlanjutan (sustainability reporting). Chariri (2009) menyatakan bahwa laporan keberlanjutan (sustainability reporting) kian menjadi trend dan kebutuhan bagi perusahaan progresif untuk menginformasikan perihal kinerja ekonomi, sosial dan lingkungannya sekaligus kepada seluruh pemangku kepentingan (stakeholders) perusahaan.

Pengembangan Hipotesis

\section{Abnormal Return Sebelum dan Sesudah Pengumuman Penghargaan ISRA}

Ross (1977) Teori sinyal menjelaskan mengapa perusahaan mempunyai dorongan untuk memberikan informasi laporan keuangan pada pihak eksternal. Dorongan perusahaan untuk memberikan informasi adalah karena terdapat asimetri informasi antara perusahaan dan pihak luar karena perusahaan mengetahui lebih banyak mengenai perusahaan dan prospek yang akan datang daripada pihak luar (investor, kreditor). Teori sinyal juga mengemukakan tentang bagaimana seharusnya sebuah perusahaan memberikan sinyal kepada pengguna laporan keuangan. Berdasarkan teori sinyal, pengumuman pemenang ISRA merupakan perusahaan yang memberikan sinyal positif bagi investor melalui Abnormal Return.

Reaksi investor ditunjukkan dengan adanya perubahan harga saham perusahaan tertentu yang cukup mencolok dari suatu sekuritas yang bersangkutan pada saat pengumuman ISRA, yang dimaksud mencolok adalah terdapat perbedaan yang cukup besar antara return yang terjadi (actual return) dengan return harapan (expected return). Dengan kata lain, terjadi return kejutan atau abnormal return pada saat pengumuman ISRA. Para investor 
membutuhkan berbagai informasi terkait dengan aktivitas perusahaan yang digunakan dalam pengambilan keputusan. Oleh karena tumbuh kembang perusahaan bergantung pada dukungan dari para investornya, maka perusahaan akan berusaha untuk memberikan berbagai informasi yang bermanfaat bagi investor dalam mengambil keputusan.

Penelitian yang dilakukan Budiman at al (2009) menyimpulkan bahwa terdapat perbedaan abnormal return saham perusahaan yang memenangkan penghargaan di ISRA, dan juga penelitian Harun Aksa (2014) menyebutkan bahwa, investor bereaksi positif terhadapa perusahaan peraih penghargaan ISRA. Serta hasil perhitungan dengan independent sample test membuktikan bahwa terdapat perbedaan perusahaan yang mendapatkan penghargaan ISRA dengan reaksi investor perusahaan yang tidak mendapat penghargaan ISRA terbukti dengan menurunnya minat investor untuk berinvestasi pada perusahaan tersebut.

$\mathrm{H}_{1}$ :Terdapat perbedaan abnormal return sebelum dan sesudah pengumuman penghargaan ISRA periode 2016

\section{Volume Perdagangan Saham Sebelum dan Sesudah Pengumuman Penghargaan ISRA Periode 2016.}

Salah satu bentuk penghargaan yang diberikan untuk perusahaan yang melaporkan kegiatan bisnis serta kegiatan kepedulian terhadap lingkungan dan sosial adalah ISRA (Indonesia Sustainability Reporting Award).Investor dapat menilai bahwa perusahaan pemenang ISRA memiliki prospek yang baik sehingga minat investor atas perusahaan tersebut meningkat. Untuk mengetahui pengaruh ISRA tahun 2016 digunakan indikator trading volume activity sebagai ukuran yang menggambarkan kegiatan perdagangan saham perusahaan-perusahaan peraih penghargaan ISRA selama tahun 2016. Trading volume activity digunakan untuk melihat apakah investor menilai pengumuman Indonesia Sustainability Reporting Award sebagai salah satu bahan pertimbangan investasi atau tidak sehingga dapat mempengaruhi volume perdagangan saham.Hal tersebut dapat dilihat melalui tinggi rendahnya volume perdagangan saham pada harihari diseputar pengumuan ISRA 2016.

Penelitian Saputro (2005) yang menganalisis perbedaan harga dan volume perdagangan saham sebelum dan sesudah pengumuman Indonesia Sustainability Reporting Award (ISRA) 2005, ditemukan bahwa tidak terdapat perbedaan volume perdagangan saham yang diukur dengan trading volume activity sebelum dan sesudah pengumuman ISRA 2005. Penelitian ini sejalan dengan penelitian Budiman dan Supatmi (2009) yang tidak menemukan perbedaan signifikan trading value activity di seputar tanggal pengumuman ISRA 2014-2016. Sedangkan penelitian yang dilakukan Suwarno (2005) yang menguji apakah penghargaan 
Annual Report Award (ARA) 2004 direspon positif oleh investor dipasar. Hasil penelitian ini menunjukan adanya peningkatan volume perdagangan saham perusahaan-perusahaan penerima ARA setelah tanggal pengumuman sama seperti Annual Report Award (ARA). Penelitian ini sejalan dengan penelitian yang dilakukan Idealfa (2011) yang menguji apakah pengumuman ICSR Award 2005-2008 direspon positif oleh pasar.

$\mathrm{H}_{2}$ :Terdapat perbedaan volume perdagangan saham sebelum dan sesudah pengumuman penghargaan ISRA periode 2016.

\section{METODE PENELITIAN}

\section{Lokasi dan Waktu Penelitian}

Penelitian dilakukan pada perusahaan-perusahaan yang memenangkan Indonesia Sustainability Reporting Awards (ISRA) pada periode 2016.

\section{Populasi dan Sampel}

Populasi dalam penelitian ini adalah perusahaan go public yang terdaftar dalam penghargaan Indonesia Sustainability Repoting (ISRA) dan periode yang dijadikan amatan adalah data pada tahun 2016. Metode pengambilan sampel dilakukan secara non-probability sampling. Teknik non-probability sampling dalam penelitian ini dengan penentuan sampel berdasarkan beberapa pertimbangan, Adapun kriteria yang digunakan adalah perusahaan yang meraih penghargaan ISRA.

\section{Tehnik Pengumpulan Data}

Pada penelitian ini, data sekunder diperoleh dari teknik dokumentasi yaitu data diperoleh dari berbagai dokumen atau literature yang berkaitan dengan permasalahan yang diteliti. Dokumen yang dimaksud adalah harga penutupan saham dan volume perdagangan saham

\section{Model dan Analisis Data}

Teknik analisis data dalam penelitian ini menggunakan teknik event study, uji normalitas data, dan uji paired sample $t$ - test. Jogiyanto (2015) menyatakan bahwa event study merupakan suatu studi yang mempelajari reaksi pasar terhadap suatu peristiwa (event) yang informasinya dipublikasikan sebagai suatu pengumuman. Event study memiliki tahapan - tahapan sebagai berikut:

1. Menentukan pengumuman Indonesia Sustainability Reporting Award (ISRA) periode 2012-2016 sebagai peristiwa yang akan dilihat reaksi pasarnya.

2. Mengidentifikasi tanggal pengumuman ISRA 2016 tanggal 16 Desember 2016 
3. Menentukan periode penelitian atau event window yaitu tiga hari sebelum dan tiga hari sesudah pengumuman ISRA periode 2016.

4. Setiap sampel perusahaan dilihat return dan aktivitas perdagangan pada masing- masing satuan periode.

5. Menghitung abnormal return dari return yang sudah didapatkan untuk setiap perusahaan.

6. Menghitung treding volume activity dari data jumlah saham yang beredar dan diperdagangkan.

\section{DefinisiOperasional Variabel}

\section{Abnormal Return}

Abnormal return merupakan kelebihan dari return yang sesungguhnya terjadi terhadap return normal. Return normal merupakan return ekspektasian (return yang diharapkan oleh investor). Dengan demikian abnormal return dapat diartikan selisih antara return sesungguhnya yang terjadi dengan return ekspektasian (Jogiyanto, 2010). Untuk menghitung abnormal return dapat menggunakan rumus sebagai berikut

\section{ARi. $t=$ Ri. $t-E[R i . t]$}

Dimana

$$
\begin{gathered}
E[\text { Ri. } t]=\frac{\text { IHSG } t-\text { IHSG } t-1}{\text { IHSG } t-1} \\
\text { Ri. } t=\frac{\text { Pit }- \text { Pit }-1}{\text { Pit }-1}
\end{gathered}
$$

Keterangan:

ARi.t = return tidak normal sekuritas ke-i pada periode peristiwa ke-t

Ri.t = return sesungguhnya yang terjadi pada sekuritas ke-I pada periode ke-t

$\mathbf{E}[\mathbf{R i . t}]=$ return ekspektasi sekuritas ke-i

Ai = konstanta sekuritas ke-i

Bi = koefesien beta sekuritas ke-i

Pi .t = harga saham sekuritas ke-i pada periode peristiwa ke-t

Pi.t - 1 = harga saham sekuritas ke-I pada periode peristiwa ke t-1

Rm.t = actual return pasar yang terjadi pada periode peristiwa ke-t

IHSGt = indeks harga saham gabungan yang terjadi pada periode peristiwa ke-t

IHSGt-1 = Harga saham gabungan yang terjadi pada periode peristiwa ke t-1 


\section{Volume Perdagangan Saham}

Volume perdagangan saham digunakan sebagai ukuran volume perdagangan saham yang digunakan untuk melihat apakah investor menilai sebuah pengumuman sebagai sinyal positif atau sinyal negatif, dalam artian apakah informasi tersebut membuat keputusan perdagangan diatas harga normal (Savitri, 2001 dalam Budiman, 2009). Magdalena (2004) mengartikan volume perdagangan saham sebagai jumlah lembar saham yang diperdagangkan pada periode tertentu. Volume perdagangan saham dapat dihitung dengan menggunakan rumus sebagai berikut :

$$
\text { TVA it }=\frac{\sum \text { saham perusahaan } \mathbf{k e}-\mathbf{i} \text { yang di perdagangkan pada waktu ke }-\mathbf{t}}{\sum \text { saham perusahaan } \mathbf{k e}-\mathbf{i} \text { yang beredar pada waktu ke }-\mathbf{t}}
$$

Setelah TVA dari masing-masing saham diketahui kemudian dihitung rata-rata TVA selama periode pengamatan dengan rumus :

$$
\text { XTV At }=\frac{\sum \text { TVAi }}{\mathrm{N}}
$$

Keterengan:

XTV At = Rata-rata TVA pada waktu ke-t

$\sum$ TVAi = Jumlah TVA pada waktu ke-t

n = Jumlah sampel

\section{HASIL PENELITIAN DAN PEMBAHASAN}

Gambaran objek penelitian

Objek penelitian adalah perusahaan yang mengikuti ajang Indonesia Sustainability Reporting Awards pada tahun 2016, Sebanyak 52 perusahaan tercatat sebagai peserta Indonesia Sustainability Reporting Awards pada tahun 2016. Dengan menggunakan waktu pengamatan selama 6 hari yang terdiri dari 3 hari sebelum dan 3 hari sesudah pengumuman Indonesia Sustainability Reporting Awards sehingga waktu penelitian dianggap cukup untuk mendapatkan sampel penelitian. 
Tabel 4.1

Kriteria Pengambilan Sampel

\begin{tabular}{lc}
\hline \multicolumn{1}{c}{ Kriteria } & Periode \\
\cline { 2 - 2 } $\begin{array}{l}\text { Perusahaan penerima penghargaan ISRA (winner, runner up } \\
\text { runner up 2) }\end{array}$ & $\mathbf{2 0 1 6}$ \\
Perusahaan yang tidak terdaftar di Bursa Efek Indonesia & 26 \\
Jumlah perusahaan yang menjadi sampel & -16 \\
Waktu pengamatan & 10 \\
Jumlah observasi (N) & 3 \\
\hline
\end{tabular}

\section{Statistik Deskriptif}

Analisis statistik deskriptif untuk pengujian sampel berpasangan (paired sample T-Tes) bertujuan untuk memberikan deskripsi dari suatu data yang dilihat dari jumlah sampel, nilai rata-rata (mean), dan standar deviasi serta standar error mean dari masing-masing sampel yang diteliti.

Tabel 4.2

Statistik Deskriptif

\begin{tabular}{lccccc}
\hline & N & Minimum & Maximum & Mean & Std.Deviation \\
\hline AR_sebelum & 30 & -0.04660 & 0.04276 & 0.00050 & 0.00050 \\
AR_sesudah & 30 & -0.03668 & 0.02486 & -0.00618 & -0.00618 \\
TVA_sebelum & 30 & 0.000001 & 0.00012 & 0.00003 & 0.00003 \\
TVA_sesudah & 30 & 0.000001 & 0.00013 & 0.00003 & 0.00003 \\
Valid N & 30 & & & & \\
\hline
\end{tabular}

Sumber : Data olahan SPSS (2017)

Uji Normalitas Data

Uji normalitas bertujuan untuk menguji apakah data dari sampel yang digunakan memiliki distribusi data normal atau tidak, sampel yang baik adalah sampel yang memiliki distribusi data normal atau mendekati normal. Uji sampel berpasangan (paired sample t-test) mengharuskan data untuk berdistribusi normal. Uji normalitas yang digunakan adalah uji kolomogorov-smirnov 
Jurnal Al-Buhuts

Volume. 1, Nomor 1, Juni 2018

Hal. 147-167
Analisis Perbandingan Reaksi Investor Sebelum Dan Sesudah Pengumuman Indonesia Sustainability Reporting Awards (ISRA) (Studi Kasus Pada Perusahaan Penerima Penghargaan ISRA Periode 2016)

Tabel 4.3

Uji Normalitas (One-Sample Kolmogrov-Smirnov)

\begin{tabular}{|c|c|c|c|c|c|}
\hline & & $\begin{array}{c}\mathrm{AR}_{-} \\
\text {SEBELU } \\
\mathrm{M}\end{array}$ & $\begin{array}{c}\mathrm{AR}_{-} \\
\text {SESUDA } \\
\mathrm{H}\end{array}$ & $\begin{array}{c}\text { TVA_- } \\
\text { SEBELU } \\
\text { M }\end{array}$ & $\begin{array}{c}\text { TVA_- }_{\text {SESUDA }} \\
\text { H }\end{array}$ \\
\hline \multicolumn{2}{|l|}{$\mathrm{N}$} & 30 & 30 & 30 & 30 \\
\hline \multirow[t]{2}{*}{ Normal Parameters ${ }^{\mathrm{a}}$} & Mean & 0.0005 & -0.0062 & 0.0000 & 0.0000 \\
\hline & Std. Deviation & 0.02105 & 0.01441 & 0.00003 & 0.00003 \\
\hline \multirow{3}{*}{$\begin{array}{l}\text { Most Extreme } \\
\text { Differences }\end{array}$} & Absolute & 0.124 & 0.089 & 0.192 & 0.192 \\
\hline & Positive & 0.124 & 0.082 & 0.192 & 0.180 \\
\hline & Negative & -0.092 & -0.089 & -0.163 & -0.192 \\
\hline \multicolumn{2}{|c|}{ Kolmogorov-Smirnov Z } & 0.682 & 0.488 & 1.049 & 1.053 \\
\hline \multicolumn{2}{|l|}{ Asymp. Sig. (2-tailed) } & 0.741 & 0.971 & 0.221 & 0.217 \\
\hline
\end{tabular}

Sumber : Data olahan SPSS (2018)

Tabel 4.3 menunjukan bahwa baik variabel AR_sebelum dan AR_sesudah maupun TVA_sebelum dan TVA_sesudah memiliki nilai Asymp.Sig yang lebih besar dari 0.05 yaitu masing-masing sebesar 0.741 dan 0.971 serta 0.221 dan 0.217. Hal ini menunjukan bahwa data Abnormal Return (AR) dan Trading Volume Activity (TVA) untuk data sepuluh perusahaan berdistribusi secara normal.

Interpretasi Model

Interpretasi untuk model pengujian sampel berpasangan (paired sample T-Tes) adalah berdasarkan nilai Mean dan nilai Sig. (2-tailed) yang terdapat pada Tabel 4.4 berikut.

Tabel 4.4

Interpretasi Model

\begin{tabular}{lccccc}
\hline & Mean & N & $\begin{array}{c}\text { Std. } \\
\text { Deviation }\end{array}$ & Sig. (2-tailed) \\
\hline H1_sebelum & 0.0005 & 30 & 0.02105 & 0.191 \\
H1_sesudah & -0.0062 & 30 & 0.01441 & \\
sebelum & 327,949 & 30 & 287383.4 & 0.382 & \\
sesudah & 270,735 & 30 & 353011 &
\end{tabular}

Sumber : Data olahan SPSS (2017)

Berdasarkan nilai Mean pada Tabel 4.5 di atas maka persamaan matematis yang dapat disusun untuk masing-masing hipotesis dalam penelitian ini adalah sebagai berikut. 
Persamaan untuk hipotesis 1

$\operatorname{Rit}_{-1}(0.0005) \neq \operatorname{Rit}_{1}(-0.0062)$

Persamaan untuk hipotesis 2

TVA- $_{1}(327,949) \neq$ TVA $_{1}(270,735)$

Dari persamaan matematis yang telah terbentuk diatas maka dapat di interpretasikan beberapa hal diantaranya adalah :

1. Nilai rata-rata (Mean) dari data abnormal return untuk sepuluh sampel perusahaan memiliki nilai yang berbeda antara sebelum dan sesudah pengumuman Indonesia Sustainability Reporting Awards masing-masing sebesar 0.0005 dan -0.0062. Namun memiliki nilai signifikan lebih besar dari 0,05 yaitu sebesar 0.191

2. Nilai rata-rata (Mean) dari data trading volume activity untuk sepuluh sampel perusahaan memiliki nilai yang berbeda antara sebelum dan sesudah pengumuman Indonesia Sustainability Reporting Awards masing-masing sebesar 327,949 dan 270,735. Namun memiliki nilai signifikan lebih besar dari 0,05 yaitu sebesar 0.382

Pengujian Hipotesis

\section{Pengujian Sampel Berpasangan (Paired Sample T-Test)}

Interpretasi terkait dengan pengujian sampel berpasangan (Paired Sample T-Test) adalah apakah terdapat perbedaan nilai rata-rata yang signifikan dari data sampel sebelum dan sesudah suatu kejadian (event). Keputusan terkait dengan uji sampel berpasangan adalah, apabila nilai signifikansi dari dua sampel yang diuji (sebelum dan sesudah) > 0,5 maka keputusannya adalah tidak terdapat perbedaan pada sampel yang diteliti setelah terjadinya suatu kejadian (event). Sebaliknya jika nilai signifikansi dari kedua sampel yang diuji $<0,5$ maka keputusannya adalah terdapat perbedaan yang signifikan pada sampel yang diteliti setelah terjadinya suatu kejadian (event). 
Tabel 4.5

Hasil uji Paired Sample T-Test (Abnormal Return)

\begin{tabular}{lrrrrrr}
\hline & \multicolumn{2}{c}{ Paired Differences } & & Df & $\begin{array}{c}\text { Sig. (2- } \\
\text { tailed) }\end{array}$ \\
\cline { 2 - 5 } & Mean & Std. Deviation & t & & Df \\
\hline $\begin{array}{l}\text { AR_sebelum - } \\
\text { AR_sesudah }\end{array}$ & 0.00668 & 0.02732 & 1.339 & & 29 & 0.191 \\
\hline Sun_s
\end{tabular}

Sumber : Data olahan SPSS (2018)

Abnormal return memiliki nilai signifikan sebesar 0.191 yang lebih besar dari 0.05. Hal ini berarti tidak terdapat perbedaan yang signifikan pada sampel perusahaan sebelum dan sesudah pengumuman Indonesia Sustainability Reporting Awards (ISRA) sehingga hipotesis pertama ditolak

Tabel 4.6

Hasil uji Paired Sample T-Test (TradingVolume Activity)

\begin{tabular}{lcccccc}
\hline & \multicolumn{2}{c}{ Paired Differences } & & Df & \multicolumn{1}{c}{$\begin{array}{c}\text { Sig. (2- } \\
\text { tailed) }\end{array}$} \\
\cline { 2 - 5 } & Mean & $\begin{array}{c}\text { Std. } \\
\text { Deviation }\end{array}$ & t & Ded & &
\end{tabular}

Sumber : Data olahan SPSS (2018)

Trading volume activity memiliki nilai signifikan sebesar 0.065 yang lebih besar dari 0.05.yang berarti tidak terdapat perbedaan yang signifikan pada sampel perusahaan sebelum dan sesudah pengumuman Indonesia Sustainability Reporting Awards (ISRA) sehingga hipotesis kedua ditolak.

Pembahasan

\section{Abnormal Return Sebelum dan Sesudah Pengumuman Penghargaan ISRA}

Hasil pengujian paired sample t-tes menunjukan bahwa terdapat perbedaan pada nilai rata-rata abnormal return sebelum dan sesudah pengumuman Indonesia Sustainability Reporting Awards (ISRA) yang dimiliki oleh perusahaan-perusahaan peraih penghargaan Indonesia Sustainability Reporting Awards (ISRA), namun perbedaan abnormal return tersebut tidak signifikan. Hal ini menunjukan bahwa meskipun perusahaan maraih penghargaan sebagai perusahaan yang melakukan tanggung jawab sosial terhadap lingkungan dan masyarakat namun tidak akan membuat investor menilai lebih harga saham yang dimiliki oleh perusahaan tersebut. Perbedaan nilai rata-rata pada tiga hari sebelum dan sesudah 
pengumuman namun tidak signifikan menunjukan bahwa perubahan return saham yang dimiliki oleh perusahaan-perusahaan peraih penghargaan merupakan perubahan harga yang wajar yang biasa terjadi meskipun tanpa informasi dari pengumuman tersebut.

Rata-rata pergerakan abnormal return dari 10 perusahaan yang menjadi sampel ditunjukan pada grafik berikut :

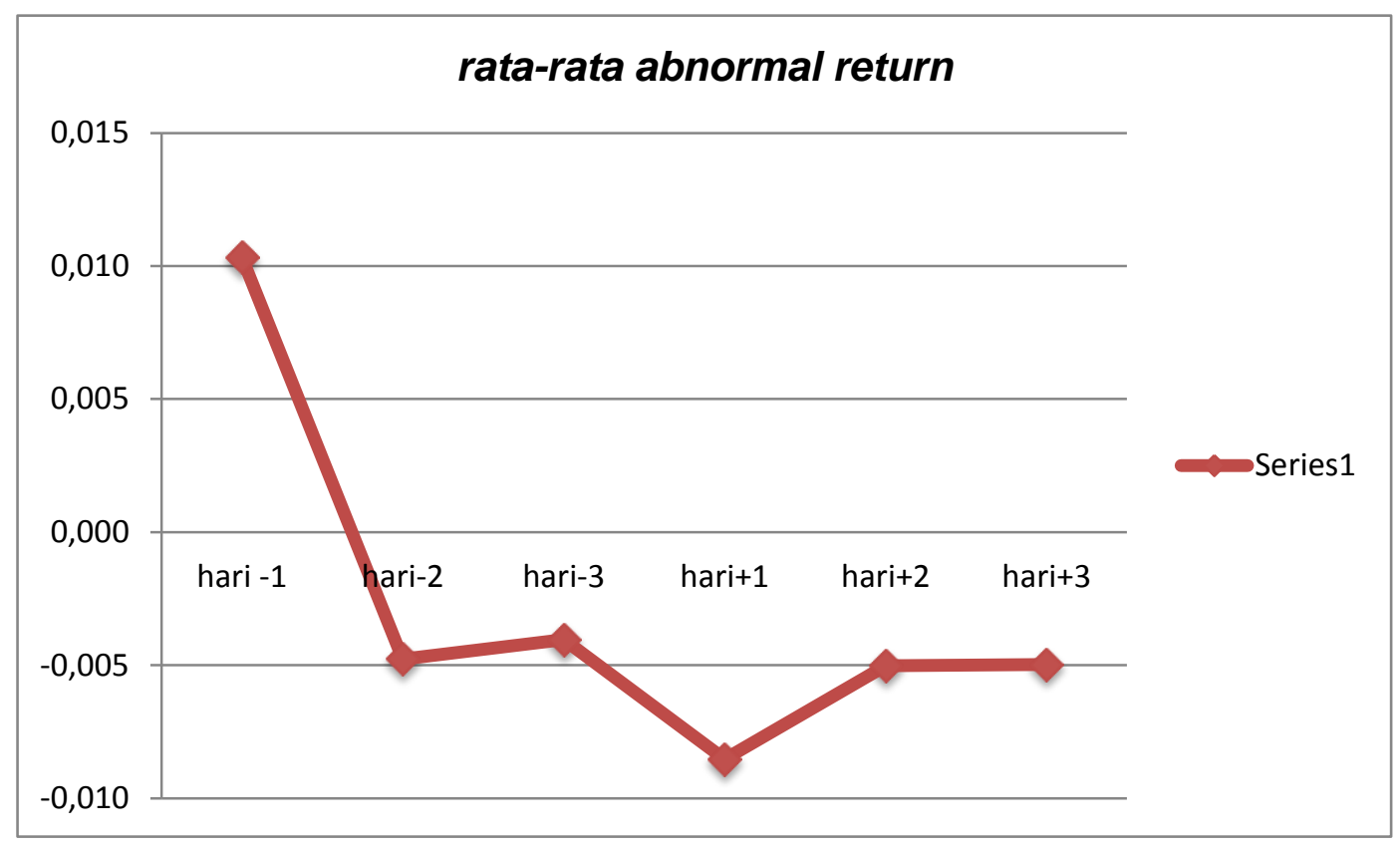

Gambar : 4.1 grafik pergerakan rata-rata abnormal return

Sumber : data olahan peneliti

Dari Grafik 4.1 terlihat bahwa pergerakan abnormal return terus menurun setiap harinya, Baik dari sebelum pengumuman maupun hingga setelah pengumuman penghargaan. Menurunnya abnormal return disebabkan oleh informasi yang diberikan oleh perusahaan kepada investor tidak mendapatkan respon yang berlebihan sehingga pergerakan return saham merupakan pergerakan yang biasa terjadi dipasar modal tanpa adanya informasi penghargaan ISRA. Hal ini dikarenakan informasi yang diberikan sudah menjadi informasi yang biasa bagi investor, Rata-rata perusahaan yang menjadi sampel penelitian merupakan perusahaanperusahaan yang telah berulang kali memperoleh penghargaan ISRA, berbeda dengan informasi seperti laba yang mengandung informasi yang sangat berharga bagi investor karena terkait langsung dengan kesejahteraan investor, informasi seperti penghargaan ISRA yang diumumkan setiap kalinya justruh akan membuat pasar merasa jenuh dengan informasi 
tersebut, investor akan menganggap informasi tersebut merupakan informasi yang biasa, Karena perusahaan tersebut telah berulang kali mendapatkan penghargaan.

Selain itu tidak signifikannya perbedaan abnormal return sebelum dan sesudah pengumuman juga dapat disebabkan oleh banyak hal di antaranya adalah.

1). Pasar modal Indonesia adalah pasar yang tidak efisien baik berdasarkan informasi maupun berdasarkan keputusan. Beberapa peneliti seperti Sari (2015) serta Safitri (2017) yang menguji efisiensi pasar modal Indonesia menemukan bahwa pasar modal Indonesia tidak efisien, pasar modal yang tidak efisien menyebabkan harga saham tidak mencerminkan informasi yang terkandung didalamnya termaksud informasi tentang perusahaan peraih penghargaan ISRA. Hal ini dapat menyebabkan return saham tidak mengalami perubahan yang signifikan setelah dilakukan pengumuman penghargaan ISRA.

2) Penghargaan dianggap sebagai pengumuman yang tidak bersifat informatif dan tidak relevan terhadap pengambilan keputusan investasi. Penduga lain yang mungkin terjadi selain pasar efisien adalah bahwa perusahaan mulai menyadari pentingnya Sustainability Reporting namun tidak demikian dengan investor, investor mungkin belum menyadari pentingnya Sustainability Reporting sebagai sesuatu yang harus dilakukan sehinga investor menganggap hal tersebut bukan merupakan informasi dan sinyal yang luarbiasa yang harus relevan dan mempengaruhi pengambilan keputusan investasi.

3) Perilaku investor yang tidak rasional dan tidak canggih. Hartono (2014:586) menambahkan bentuk efisiensi pasar menjadi efisiensi pasar berdasarkan keputusan, dimana pasar dikatakan efisien apabila harga sekuritas dalam pasar tersebut mencerminkan segalan informasi yang tersedia dan digunakan (diolah) seefektif dan secanggih mungkin dalam pengambilan keputusan sehingga keputusan yang diambil berdasarkan infomasi tersebut dapat mempengaruhi harga saham yang dimiliki perusahaan.Dalam hal ini, investor tidak canggih dalam menganalisis informasi yang terkandung dalam pengumuman Indonesia Sustainability Reporting Awards(ISRA).Menurut Hartono (2014:591-592) bahwa informasi seperti pengumuman laba tidak perlu analisis lebih lanjut mengenai kandungan informasi yang dimiliki, namun informasi seperti penghargaan ISRA perlu untuk dianalisis lebih lanjut agar dapat mempertimbangkan nilai ekonomis dari informasi yang dimiliki. Investor yang canggih akan menganalisis informasi ini lebih lanjut dan akan melakukan keputusan yang tepat yang akan mempengaruhi harga saham dan abnormal return perusahaan. 
4) Ketidak canggihan investor dalam menganalisis informasi menyebabkan penghargaan penting dalam bidang lingkungan hidup dan tanggung jawab sosial yang seharusnya bernilai ekonimis menjadi tidak berharga sehingga harga saham tidak mencerminkan infomasi berharga yang terkandung setelah diadakan pengumuman tersebut.

5) Informasi tidak tersedia secara cepat dan dibutuhkan waktu untuk menganilisis informasi yang terkandung dari pengumuman ISRA. Infromasi yang tidak tersedia secara cepat menyebabkan reaksi investor terhadap suatu informasi menjadi lambat.selain itu, untuk menganalisis informasi diperlukan waktu sehingga harga saham tidak harus mencerminkan nilai informasi yang terkandung secara seketika namun cukup dalam waktu yang cepat (Hartono:605) dangan kata lain bahwa informasi pengumuman ISRA mungkin mempengaruhi abnormal return namun tidak tercermin dalam periode pengamatan yaitu tiga hari setelah pengumuman. Waktu penelitian yang singkat menyebabkan tidak terdapat perbedaan yang signifikan pada abnormal return perusahaan karena investor masi memerlukan waktu untuk dapat menganalisis dan mengambil keputusan yang akan mempengaruhi harga saham dan abnormal return.

Penelitian ini sejalan dengan signaling theory yang dikemukakan oleh Ross (1997), dimana sinyal yang diberikan pada investor melalui pengumuman ISRA dianggap sebagai informasi biasa dan tidak mempengaruhi keputusan untuk membeli atau menjual saham yang dimiliki sehingga tidak terdapat perbedaan return saham yang signifikan sebelum dan sesudah pengumuman. Hasil penelitian ini juga berlandaskan pada argumentasi teori pasar efisien (eficien market theory). Selain itu, penelitian ini sejalan dengan penelitian Purnawasari (2017) serta Akis dan Siti (2011) yang tidak menemukan adanya perbedaan abnormal return yang singnifikan sebelum dan setelah diadakan pengumuman Indonesia Sustainability Reporting Awards(ISRA).

\section{Trading volume activity Sebelum dan Sesudah Pengumuman Penghargaan ISRA}

Pengujian hipotesis kedua menunjukan hasil yang konsisten dengan hasil dari pengujian hipotesis pertama, dimana tidak terdapat perbedaan yang signifikan pada volume perdagangan saham sebelum dan sesudah pengumuman ISRA.Terdapatnya perbedaan namun tidak signifikan pada volume perdagangan saham menunjukan bahwa perubahan volume perdagangan merupakan pergerakan yang wajar dan bukan disebabkan oleh pengumuman penghargaan ISRA. Hal ini juga menunjukan bahwa investor tidak akan terpengaruh dengan pengumuman ISRA untuk memperdagangkan saham perusahaan peraih penghargaan. Hasil 
dari pengujian ini didukung oleh hasil pengujian dari hipotesis pertama, dimana tidak terdapatnya abnormal return membuat investor tidak tertarik untuk memperdagangkan saham perusahaan karena investor tidak akan dapat menikmati return yang tidak normal sebagai akibat dari spekulasi harga yang terjadi.

Perusahaan yang sahamnya mengandung imbal hasil (return) akan lebih banyak diperdagangkan dibandingkan dengan saham yang tidak mengandung imbal hasil (return) hal ini dikarenakan investor menginginkan keuntungan atas selisih nilai beli dan nilai jual. Berdasarkan signaling theory bahwa informasi yang diumumkan sebagai sinyal kepada pasar tidak mendapat respon dari investor karena menganggap informasi tersebut bukan merupakan informasi yang baik yang dapat mempengaruhi keputusan investor untuk bertransaksi, hal ini dapat disebabkan karena investor tidak menyadari pentingnya tanggung jawab sosial yang telah dilakukan oleh perusahaan yang dapat menjamin kelangsungan hidup perusahaan, sehingga investor tidak menilai lebih harga saham yang dimiliki perusahaan peraih penghargaa ISRA dan tidak bersedia untuk melakukan transaksi atas saham yang dimiliki.

Sejalan dengan signaling theory, teori pasar efisien juga mengindikasikan bahwa informasi yang diterima tidak diproses oleh investor dalam rangka pengambilan keputusan sehingga keputusan yang bernilai ekonomis tidak tercermin dalam nilai saham dan tidak mengandung return yang akanmenyebabkan investor tidak tertarik untuk membeli dan menjual saham perusahaan peraih penghargaan ISRA. Dengan kata lain bahwa alasan utama yang menyebabkan ditolaknya hipotesis pertama dan kedua yang diajukan dalam penelitian ini adalah, karena investor tidak cukup rasional dan canggih dalam mengolah informasi sehingga perusahaan yang mempunya informasi sebagai sinyal baik dapat dirugikan karena informasi seperti penghargaan Indonesia Sustainability Reporting Awards (ISRA) seharusnya mengandung informasi yang berharga yang dapat menjamin kelangsungan hidup perusahaan dilingkungan perusahaan tersebut beroperasi karena adanya dukungan dari masyarakat setempat khususnya yang mendapatkan manfaat dari tanggung jawab sosial yang telah dilakukan oleh perusahaan.

Penelitian ini sejalan dengan penelitian yang dilakukan oleh Purnawasari (2017) serta Akis dan Siti (2011) yang tidak menemukan adanya perbedaan yang signifikan pada volume perdagangan saham-saham perusahaan peraih penghargaan Indonesia Sustainability Reporting Awards (ISRA). Serta didukung oleh teori efisiensi pasar dan signaling theory.

\section{PENUTUP}

Kesimpulan 
Berdasarkan hasil penelitian dan pembahasan yang telah dilakukan maka kesimpulan yang dapat diberikan diantaranya adalah :

1. Hipotesis pertama ditolak dikarenakan beberapa hal diantaranya adalah.

a) Pasar modal Indonesia adalah pasar yang tidak efisien baik berdasarkan informasi maupun berdasarkan keputusan.

b) penghargaan dianggap sebagai pengumuman yang tidak bersifat informatif dan tidak relevan terhadap pengambilan keputusan investasi

c) perilaku investor yang tidak rasional dan tidak canggih

d) informasi tidak tersedia secara cepat dan dibutuhkan waktu untuk menganilisis informasi yang terkandung dari pengumuman ISRA

2. Hipoteisis kedua ditolak karena tidak terdapatnya abnormal return sehingga membuat investor tidak tertarik untuk memperdagangkan saham perusahaan karena investor tidak akan dapat menikmati return yang tidak normal sebagai akibat dari spekulasi harga yang terjadi

Keterbatasan Penelitian

Dalam penelitian ini masih terdapat keterbatasan-keterbatasan yang memerlukan penyempurnaan untuk penelitian yang akan datang, antara lain :

1. Waktu pengamatan yang terlalu singkat yaitu hanya tiga hari sebelum dan sesudah pengumuman Indonesia Sustainability Reporting Awards (ISRA), sehingga hasil penelitian mungkin bias terhadap lamanya waktu yang dibutuhkan untuk pengambilan keputusan.

2. Pengukuran terhadap variabel abnormal return hanya menggunakan satu pengukuran Saran

Dari keterbatasan yang telah disebutkan maka penelitian selanjutnya diharapkan untuk dapat melengkapai keterbatasan dari penelitian ini dengan saran-saran berikut :

1. Waktu pengamatan ditambahkan selama 5 sampai 30 hari agar waktu pengamatan cukup untuk melihat perubahan abnormal return dan trading volume activity yang terjadi dalam waktu yang lebih lama, hal ini karena mengingat karakteristik Bursa Efek Indonesia yang mungkin membutuhkan waktu yang cukup lama untuk dapat merespon informasi dalam harga saham.

2. Pengukuran untuk abnormal return hendaknya digunakan model yang lain seperti Market Model dan Mean Adjusted Model 


\section{DAFTAR PUSTAKA}

ACCA.The Association of Chartered Certified Accountants. 2013. The Business Benefits Of Sustainability Reporting in Singapore. Singapore.

Akis, A. R dan Siti Mutmainah. 2011. Pengaruh pengumuman indonesia sustainability reporting award (ISRA) terhadap abnormal return dan volume perdagangan saham (studi kasus pada perusahaan peraih penghargaan isra 2009-2010). Semarang. Volume 7/No. 2/MEI 2011 : 122 - 133

Aksa, Harun. 2014. Reaksi Investor Terhadap Pengumuman Indonesia Sustainability Report Award (ISRA) (Studi pada Perusahaan Peserta ISRA periode 2011 - 2013).

Aldair R. A. dan Siti M. 2011.Pengaruh Pengumuman Indonesia Sustainability Reporting Award (ISRA) terhadap Abnormal Return dan Volume Perdagangan Saham (Studi Kasus pada Perusahaan Peraih Penghargaan ISRA 2009-2010).Jurnal Akuntansi dan Auditing.Vol. 7, No. 2.

Anggraini, Fr.R. Retno. 2006. Pengungkapan Informasi Sosial dan Faktor Faktor yang Mempengaruhi Pengungkapan Informasi Sosial dalam Laporan Keuangan Tahunan (Studi Empiris pada Perusahaan-Perusahaan yang terdaftar di Bursa Efek Indonesia). Simposium Nasional Akuntansi IX. Padang. Agustus: 54-58.

Ballou, Brian, L. Heitger, dan Charles E. Landes. 2006. The Future of Corporate Sustainability Reporting: A Rapidly Growing Assurance Opportunity.http://www.journalofaccountancy.com/. Diunduh tanggal 4, bulanSeptember, tahun 2017.

Brigham, Eugene dan Houston Joel.2001. Manajemen Keuangan.Jakarta: Erlangga.

Budiman, Ferry dan Supatmi. 2009. Pengaruh Pengumuman Indonesia SustainabilityReporting Award (ISRA) terhadapabnormal return dan volume perdagangan saham (Studi Kasus padaPerusahaan Pemenang ISRA Periode20052008). Makalah disampaikan dalam Simposium Nasional Akuntansi XII Palembang.

Chang, Man Kit. 1998. Predicting unethical behavior: A comparison of the theoryof reasoned. Journal of Business Ethics, 17(16): h: 1825.

Chariri, A., and Gozali, I. 2007. TeoriAkuntansi (trans: Accounting Theory Semarang: Badan Penerbit UNDIP, ISBN 979.704.0143.3.

Daniri, M. Achmad. 2008. Standarisasi Tanggung Jawab Sosial Perusahaan. Http:/www.madani-ri/2008/01/17/ standarisasi tanggung - jawab - sosial perusahaan/.[12September2017].

Dewi, K. E. C dan Sudana, P. 2015. Sustainability Reporting dan Profitabilitas (studi pada pemenang Indonesian Sustainability Reporting awards).Bali. Nomor ISSN 2302-855.

Effendi, M.A. 2012.Pelaporan Berkelanjutan (Sustainability Reporting) sebagai Implementasi

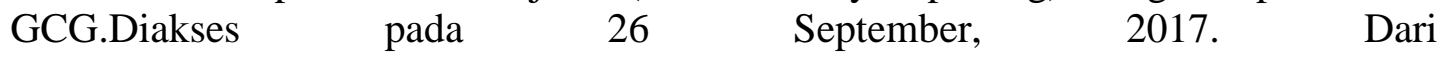


https://muhariefeffendi.wordpress.com/201205/30/pelaporan-berkelanjutansustainability-reporting-sebagai-implentasi-gcg/

Elkington, John. 1997. Cannibals with Forks, the Triple Bottom Line of Twentieth Century Business. Oxford: CapstonePublishing Ltd.

Fachrizal dan Teuku M. M. R. 2016. Analisis Perbandingan Kinerja Keuangan, Abnormal Return dan Volume Perdagangan Saham antara Periode Sebelum dan Sesudah Meraih Indonesia Sustainability Reporting Award (ISRA). Jurnal Ilmiah Mahasiswa Ekonomi (JIMEKA).Vol. 1, No. 2.

Ferry B. dan Supatmi. 2009. Pengaruh Pengumuman Indonesia Sustainability Reporting Award (ISRA)Terhadap Abnormal Return dan Volume Perdagangan Saham (Studi Kasus pada Perusahaan Pemenang ISRA Periode 2005-2008. Jurnal Simposium Nasional Akuntansi XII, Palembang.

GRI-G3.1 Guidliness. 2011. Sustainability Reporting Guidliness. www.globalreporting.org. Diunduh tanggal 6, bulan Agustus, tahun 2017

I Gusti Ngurah B. P. D. S., Gede Adi Y, dan Ni Kadek S. 2015.PengaruhPengumuman Indonesia Sustainability Reporting Award (ISRA) terhadap Abnormal Return dan Volume Perdagangan Saham (Studi Empiris pada Perusahaan Pemenang Indonesia Sustainability Reporting Award Tahun 2009-2013).e-Jurnal S1 Ak Universitas Pendidik an Ganesha. Vol. 3, No. 1.

Jogiyanto, Hartono. 2010. Teori Portofolio dan Analisis Investasi. Yogyakarta:BPFE Yogyakarta, Edisi Kelima.

Jogiyanto Hartono. 2007. Teori Portofolio dan Analisis Investasi. Yogyakarta: BPFEYogyakarta .Studi Peristiwa: Menguji Reaksi Pasar Modal Akibat Suatu Peristiwa. Penerbit BPFE Yogyakarta, Yogyakarta.

Maharrani, Y. 2014. Analisis Perbandingan Reaksi Investor Antara Perusahaan yang Memperoleh Penghargaan dengan Perusahaan yang Tidak Memperoleh Penghargaan Indonesian Sustainability Reporting Award (ISRA).Jember.

Nuryana, Mu'man. 2005. Corporate Social Responsibility dan Kontribusi bagi Pembangunan Berkelanjutan. Makalah Diklat. Diklat Pekerjaan Sosial Industri.Balai Besar Pendidikan dan Pelatihan Kesejahteraan Sosial (BBPPKS).5 Desember. Bandung

Pemerintah Indonesia. 1997. Undang-Undang No. 23 tahun 1997 tentang Pengelolaan Lingkungan Hidup.

Pemerintah Indonesia. 2007. Undang-Undang No. 40 tahun 2007 tentang Perseroan Terbatas.

Pramastuti, Suluh. 2007. Analisis Kebijakan Dividen : pengujian Dividend Signaling Theory dan Rent Extraction Hypotesis (Thesis). Pasca Sarjana Jurusan Manajemen Megister Sains Ilmu-ilmu Manajemen Universitas Gajah Mada, Yogyakarta.

Purnawasari, H. 2017. Analisis perbedaan reaksi pasar sebelum dan sesudah pengumuman Indonesia sustainability reporting award (isra) (studi kasus pada perusahaan penerima penghargaan isra periode 2012-2016). Yogyakarta. 
Randika B. L. dan Yeterina W. N. 2014.Perbedaan Reaksi Pasar pada Perusahaan Pemenang Indonesia Sustainability Reporting Award (ISRA) (Studi Kasus pada Perusahaan Pemenang ISRA periode 2009 -2011). Jurnal Telaah Bisnis. Vol. 15,No. 1.

Ross. S. A. 1977. The Determination of Financial Structure: The Incetive-Signalling Approach. The Bell Journal of Economics, 23-40.

Safitri, Rizka. 2017. Pengujian Efisiensi Pasar Bentuk Setengah Kuat Melalui Pengumuman Inisiasi Dividen (Studi Pada Perusahaan Yang Melakukan Cash Dividend Di Bursa Efek Indonesia). Skripsi Universitas Bandar Lampung

Sari, novita.2015.Pengujian Efisiensi Pasar Bentuk Setengah Kuat Secara Keputusan Terhadap Inisiasi Dividen Pada Perusahaan Yang Terdaftar Di Bursa Efek Indonesia.Skripsi universitas negeri yogyakarta

Satyo. 2005. Disukai Konsumen, Diminati Investor. Media Akuntansi, Edisi 47/TahunXII/Juli 2005.http://www.yahoo.finance.com. [10 September 2017].

Segger, Claire Cordonier, dan Marie. 2003.Sustainability and Corporate Accountability Regimes: Implementing the Johannesburg Sunnit Agenda.Reciel, 12(3): h: 295.

Suwardjono. 2005. Teori Akuntansi: Perekayasaan Pelaporan Keuangan. Edisi Ketiga, Yogjakarta: BPFE.

Wibisono, Y. 2007. "Membedah Konsep dan Aplikasi CSR”. Gresik: Fascho Publishing.

World Business Council for Sustainable Development 2002, Corporate Social Responsibility: The WBCSD's journey, pp. 1. Retrieved mei, 2015. From http://www.wbcsd.org

https://muhariefeffendi.wordpress.com/2017/09/12/pelaporan-berkelanjutan sustainabilityreporting-sebagai-implementasi-gcg/

https://datakata.wordpress.com/tag/teori-akuntansi/

www.isra.ncsrid.org 